Editorial

\title{
Exploring Digital Native News Media
}

\author{
Ramón Salaverría \\ School of Communication, University of Navarra, 31009 Pamplona, Spain; E-Mail: rsalaver@unav.es
}

Submitted: 20 March 2020 | Published: 16 April 2020

\begin{abstract}
Digital native news media are becoming a blooming phenomenon, expanding globally. Up until now, however, the scholar community has paid little attention to online-born media, compared to the high interest devoted to the legacy media brands. Drawing upon the extant literature on this emerging topic, this editorial summarizes the empirical and theoretical contributions of the thematic issue entitled "Digital Native News Media: Trends and Challenges." The author highlights that the studies selected for this thematic issue not only explore the innovative characteristics and opportunities of digital native media in thirty countries, but also provide a cautionary tale about their structural problems and limitations.
\end{abstract}

\section{Keywords}

digital journalism; digital native media; legacy media; media; newswork; online-born media

\section{Issue}

This editorial is part of the issue "Digital Native News Media: Trends and Challenges," edited by Ramón Salaverría (University of Navarra, Spain).

(C) 2020 by the author; licensee Cogitatio (Lisbon, Portugal). This article is licensed under a Creative Commons Attribution 4.0 International License (CC BY).

In 2020, providing a definition of digital news media, whether native or not, is not an easy task. A quarter of a century ago, when the first news publications appeared on the Web, the imprecise label 'new media' was broadly used to designate all types of digital publications. In recent years, however, journalism scholars and practitioners have started to distinguish between 'legacy' digital publications, meaning those derived from consolidated journalistic brands, and new online publications, characterized by their digital nature and recent origin. These latest publications have been labeled in various ways, such as 'digital-born' (Nicholls, Shabbir, \& Nielsen, 2016), 'digital-native' (Pew Research Center, 2015; Wu, 2016), 'online-native' (Harlow \& Salaverría, 2016), or even simply as 'pure players' (Sirkkunen \& Cook, 2012) or 'start-ups' (Naldi \& Picard, 2012; Wagemans, Witschge, \& Deuze, 2016).

No matter the term used, recent research has found that digital native media proceed according to specific principles, relatively different from those used by nonnative media (Küng, 2015; Tandoc, 2018). Their digital nature emphasizes the tendency towards an early adoption of new technologies (Nee, 2013), as well as a deeper experimentation with multimedia storytelling formats (Harbers, 2016) and more diversification in busi- ness models (Arrese \& Kaufmann, 2016; Sirkkunen \& Cook, 2012). Beyond such structural aspects, digital native media show also, at least to some extent, a specific implementation of news values (Canter, 2018; Kilgo, Harlow, García-Perdomo, \& Salaverría, 2018) and a distinctive approach to covering the news (Higgins Joyce \& Harlow, 2020; Thomas \& Cushion, 2019).

To date, most empirical research about the digital native news media phenomenon has been limited to case studies, exploring either global-reaching brands (Tandoc, 2018) or some local cases (Harbers, 2016; Wagemans et al., 2016). However, one of the main limitations of case studies is that they usually focus on the most successful and well-developed examples, the characteristics of which hardly apply to the average publications. In order to get a more nuanced idea about the contributions and problems of the average digital native news media, broader studies are needed. This is the main contribution of this issue of Media and Communication: Offering a comprehensive overview of the characteristics and trends of digital native news media at the beginning of the third decade of the 21st century.

This thematic issue consists of 14 research articles that explore the typology, strategies, and limitations of online media. The empirical studies, some of them com- 
parative and cross-national, cover media located in more than thirty countries of the world, distributed between Europe, North and South America. The research methodologies used are also diverse, comprising quantitative, qualitative and mixed approaches. The reader will find everything from descriptive studies comparing formal elements of the media, to algorithm-based data analyses. Most studies focus on identifying the characteristics of digital native media, although there are also some that explore the dynamics of their audiences and even the professional routines of their journalists. In short, this thematic issue brings a set of diverse and consistent studies which helps to expand the attention given to an emerging area of journalism studies.

From a geographical point of view, four articles portray the blooming phenomenon of digital native news media in Latin America. Rodríguez-Hidalgo, Rivera-Rogel, and Romero-Rodríguez (2020) weigh the level of structural development of the most salient digital native media brands in the 20 countries of the region, through a descriptive analysis of various technical and formal dimensions. Based on a comparative multiple-case study, Tejedor, Ventín, Cervi, Pulido, and Tusa (2020) review, for their part, the typology of business models used by the most successful digital native news media. A similar approach can be found in the study of da Silva and Gruszynski Sanseverino (2020), who explore the community-building strategies taken by four digital native news media in Latin America and Europe, as a means for creating sustainable business models. Finally, Rojas-Torrijos, Caro-González, and González-Alba (2020) examine the editorial strategies and business opportunities of thirteen independent Latin American podcasting initiatives, not linked to legacy brands.

Europe concentrates most of the empirical studies of this thematic issue. Based on two case studies on startups from Sweden and Finland, Appelgren and Lindén (2020) show the usefulness of certain journalistic routines, in this case those linked to data journalism, to promote business projects in the periphery of journalism. García-Orosa, López-García, and Vázquez-Herrero (2020) bring a multiple case study that compares six renowned native publications of the Netherlands, Spain, Switzerland, Italy, France, and Portugal. In their study, they find in these media a combination of traditional and new journalistic routines, which allows them to draw some boundaries of digital native journalism beyond technology. For his part, Vara-Miguel (2020) analyzes the differences between the users of legacy and digital native news media in five European countries: United Kingdom, Germany, France, Italy and Spain.

The native digital media in Spain are the subject of up to five studies. Drawing upon a database of their own production that catalogs 3,862 native and non-native digital news outlets, Negredo, Martínez-Costa, Breiner, and Salaverría (2020) reveal not only a nuanced quantitative profile of digital media in Spain, but, in particular, the keys of an apparently paradoxical phenomenon:
The multiplication of digital native news media that occurred in Spain during the years of the Great Recession (2008-2014). Also based on a large volume of data, almost 100,000 user-comments from three major Spanish digital native newspapers, Castellano Parra, Ayerdi, and Peña Fernández (2020) analyze the quality of the deliberative debate in the comments of those media's news. For their part, Majó-Vázquez, Cardenal, Sagarra, and de Simón (2020) use algorithmic methods to determine the degree of informative relevance achieved by digital native news media in the country; according to their findings, the legacy news media retain control of the brokerage positions for the general population, but digital native media are gaining relevance among younger news consumers. Pérez-Díaz, Medina, and Langa (2020) also compare the Spanish legacy and native media, although in their case they examine their respective accountability practices. The fifth study on Spain, by Mendez, Palomo, and Rivera (2020), shows the particular adaptation of journalists working in native media to the use of social networks both as an information source and as an editorial tool.

This thematic issue is completed by a couple of highly recommended studies that warn about the weaknesses and problems that affect many digital native news media. Avoiding the blindly enthusiastic vision about the possibilities of this type of media that is found in some discourses, these studies remind that these media still have a long way to go until they reach consolidation. Based on a study of 15 digital native news media in Germany, Buschow (2020) identifies various patterns in the failure of these publications, during their initial stage as start-ups. In his study he offers very revealing conclusions that, beyond their academic interest, can serve as a guide for mistakes to avoid for digital media entrepreneurs. Finally, by analyzing the evolution of media audiences in the United States, Nelson (2020) presents evidence that legacy media are more resilient than some authors have announced.

Digital native news media are here to stay, but their path to consolidation may be harder than some believe. This thematic issue brings valuable data and evidencebased insights about the initial steps of this process.

\section{Acknowledgments}

The author would like to thank the Ministry of Science, Innovation and Universities of Spain for the financial support to this thematic issue through the DIGINATIVEMEDIA (RTI2018-093346-B-C31) research project.

\section{Conflict of Interests}

The author declares no conflict of interests.

\section{References}

Appelgren, E., \& Lindén, C.-G. (2020). Data journalism as a service: Digital native data journalism expertise 
and product development. Media and Communication, 8(2), 62-72.

Arrese, Á., \& Kaufmann, J. (2016). Legacy and native news brands online: Do they show different news consumption patterns? International Journal on Media Management, 18(2), 75-97. https://doi.org/ 10.1080/14241277.2016.1200581

Buschow, C. (2020). Why do digital native news media fail? An investigation of failure in the early start-up phase. Media and Communication, 8(2), 51-61.

Canter, L. (2018). It's not all cat videos: Moving beyond legacy media and tackling the challenges of mapping news values on digital native websites. Digital Journalism, 6(8), 1101-1112. https://doi.org/ 10.1080/21670811.2018.1503058

Castellano Parra, O., Ayerdi, K. M., \& Peña Fernández, S. (2020). Behind the comments section: The ethics of digital native news discussions. Media and Communication, 8(2), 86-97.

da Silva, G. C., \& Sanseverino, G. G. (2020). Business model innovation in news media: Fostering new relationships to stimulate support from readers. Media and Communication, 8(2), 28-39.

García-Orosa, B., López-García, X., \& Vázquez-Herrero, J. (2020). Journalism in digital native media: Beyond technological determinism. Media and Communication, 8(2), 5-15.

Harbers, F. (2016). Time to engage: De Correspondent's redefinition of journalistic quality. Digital Journalism, 4(4), 494-511. https://doi.org/10.1080/ 21670811.2015 .1124726

Harlow, S., \& Salaverría, R. (2016). Regenerating journalism: Exploring the 'alternativeness' and 'digitalness' of online-native media in Latin America. Digital Journalism, 4(8), 1001-1019. https://doi.org/ 10.1080/21670811.2015.1135752

Higgins Joyce, V. D. M., \& Harlow, S. (2020). Seeking transnational, digital-native news from Latin America: An audience analysis through the lens of social capital. Journalism Studies. Advance online publication. https://doi.org/10.1080/1461670X. 2020.1734858

Kilgo, D. K., Harlow, S., García-Perdomo, V., \& Salaverría, R. (2018). A new sensation? An international exploration of sensationalism and social media recommendations in online news publications. Journalism, 19(11), 1497-1516. https://doi.org/10.1177/ 1464884916683549

Küng, L. (2015). Innovators in digital news. London: Bloomsbury.

Majó-Vázquez, S., Cardenal, A. S., Sagarra, O., \& de Simón, P. C. (2020). Media roles in the online news domain: Authorities and emergent audience brokers. Media and Communication, 8(2), 98-111.

Mendez, A., Palomo, B., \& Rivera, A. (2020). Managing social networks in online-native newsrooms: When less means more. Media and Communication, 8(2), 124-134.
Naldi, L., \& Picard, R. G. (2012). "Let's start an online news site": Opportunities, resources, strategy, and formational myopia in startups. Journal of Media Business Studies, 9(4), 69-97. https://doi.org/ 10.1080/16522354.2012.11073556

Nee, R. C. (2013). Creative destruction: An exploratory study of how digitally native news nonprofits are innovating online journalism practices. International Journal on Media Management, 15(1), 3-22. https:// doi.org/10.1080/14241277.2012.732153

Negredo, S., Martínez-Costa, M.-P., Breiner, J., \& Salaverría, R. (2020). Journalism expands in spite of the crisis: Digital-native news media in Spain. Media and Communication, 8(2), 73-85.

Nelson, J. L. (2020). The enduring popularity of legacy journalism: An analysis of online audience data. Media and Communication, 8(2), 40-50.

Nicholls, T., Shabbir, N., \& Nielsen, R. K. (2016). Digital-born news media in Europe. Oxford: Reuters Institute for the Study of Journalism. Retrieved from https://ora.ox.ac.uk/objects/uuid:0037eea3-8f974bf3-a336-f86e21abfd0b

Pérez-Díaz, P.-L., Medina, Z. R., \& Langa, E. A. (2020). Between self-regulation and participatory monitoring: Comparing digital news media accountability practices in Spain. Media and Communication, 8(2), 112-123.

Pew Research Center. (2015). Digital: Top 50 digital native news sites (2015). Washington, DC: Pew Research Center. Retrieved from https://www.pew research.org/wp-content/uploads/sites/8/2017/ 05/state-of-the-news-media-report-2015-final.pdf

Rodríguez-Hidalgo, C., Rivera-Rogel, D., \& RomeroRodríguez, L. (2020). Information quality in Latin American digital native media: Analysis based on structured dimensions and indicators. Media and Communication, 8(2), 135-145.

Rojas-Torrijos, J. L., Caro-González, F. J., \& González-Alba, J. A. (2020). The emergence of native podcasts in journalism: Editorial strategies and business opportunities in Latin America. Media and Communication, 8(2), 159-170.

Sirkkunen, E., \& Cook, C. (2012). Chasing sustainability on the net: International research on 69 journalistic pure players and their business models. Tampere: University of Tampere. Retrieved from https://trepo. tuni.fi/handle/10024/66378

Tandoc, E. C., Jr. (2018). Five ways BuzzFeed is preserving (or transforming) the journalistic field. Journalism, 19(2), 200-216. https://doi.org/10.1177/ 1464884917691785

Tejedor, S., Ventín, A., Cervi, L., Pulido, C., \& Tusa, F. (2020). Native media and business models: Comparative study of 14 successful experiences in Latin America. Media and Communication, 8(2), 146-158.

Thomas, R., \& Cushion, S. (2019). Towards an institutional news logic of digital native news media? A case study of BuzzFeed's reporting during the 2015 
and 2017 UK general election campaigns. Digital Journalism, 7(10), 1328-1345. https://doi.org/10.1080/ 21670811.2019.1661262

Vara-Miguel, A. (2020). Cross-national similarities and differences between legacy and digital-born news media audiences. Media and Communication, 8(2), 16-27.

Wagemans, A., Witschge, T., \& Deuze, M. (2016). Ideology as resource in entrepreneurial journalism: The
French online news startup Mediapart. Journalism Practice, 10(2), 160-177. https://doi.org/10.1080/ 17512786.2015.1124732

Wu, L. (2016). Did you get the buzz? Are digital native media becoming mainstream? ISOJ Journal, 6(1), 131-149. Retrieved from https://isojjournal. wordpress.com/2016/04/14/did-you-get-the-buzzare-digital-native-media-becoming-mainstream

\section{About the Author}

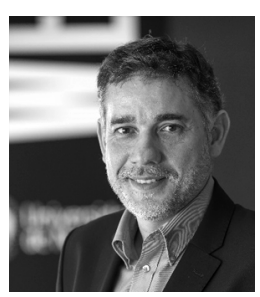

Ramón Salaverría (PhD) is Associate Professor of Journalism at the University of Navarra, where he serves as Associate Dean of Research at the School of Communication. Counting over 200 scholar publications, his research focuses on digital journalism, mostly on digital news media production. He was chair of the Journalism Studies Section of ECREA in the term 2010-2012. 